\title{
RELATIONSHIP BETWEEN DENTAL MORPHOLOGY, SEX, BODY LENGTH AND AGE IN Pontoporia blainvillei AND Sotalia fluviatilis (CETACEA) IN NORTHERN RIO DE JANEIRO, BRAZIL
}

\author{
RAMOS, R. M. A., DI BENEDITTO, A. P. M. and LIMA, N. R. W. \\ Universidade Estadual do Norte Fluminense, Centro de Biociências e Biotecnologia, Laboratório de Ciências \\ Ambientais, Av. Alberto Lamego, 2000, CEP 28015-620, Campos, RJ, Brazil \\ Correspondence to: Renata M. A. Ramos, Universidade Estadual do Norte Fluminense, Centro de \\ Biociências e Biotecnologia, Laboratório de Ciências Ambientais, Av. Alberto Lamego, 2000, \\ CEP 28015-620, Campos, RJ, Brazil, e-mail: renata@cbb.uenf.br \\ Received December 10, 1998 - Accepted February 1, 1999 - Distributed May 31, 2000
}

(With 3 figures)

\begin{abstract}
The relationship between dental morphology, sex, body length and age of small cetaceans can be used to determine ontogeny, sexual dimorphism and geographical variation. The objective of this study was to determine the relationship between dental morphology, sex, body size and age. A total of 91 specimens of $P$. blainvillei and 80 specimens of $S$. fluviatilis accidentally captured in fisheries or stranded in northern Rio de Janeiro (21 $37^{\circ}-22^{\circ} 25^{\prime}$ S S), from September 1988 to November 1996 were analysed. The teeth root diameter in P. blainvillei was significantly different between the sex; the values for females were larger than males. In neither species aid we observed significant in variations dimension and number of teeth, thickness of dentine and cemental layers and in the maximum width of cement as a function of body size. Age was related to increases in tooth length, root and cingulum diameters, and maximum width of cement in individuals of $P$. blainvillei, and tooth and crown lengths and maximum width of cement in individuals of $S$. fluviatilis. The observation of a linear growth between maximum width of cement and age in both species indicates that the equations obtained can be used to estimate relative age in P. blainvillei and S. fluviatilis in northern of Rio de Janeiro.
\end{abstract}

Key words: Pontoporia blainvillei, Sotalia fluviatilis, dental morphology, age, small cetaceans.

\section{RESUMO}

\section{Relação entre a morfologia dental, sexo, comprimento do corpo e idade em Pontoporia blainvillei e Sotalia fluviatilis (Cetacea) no Norte do Rio de Janeiro, Brasil}

A relação entre a morfologia dental, o sexo, o comprimento corpóreo e a idade em pequenos cetáceos pode ser utilizada para determinar ontogenia, dimorfismo sexual e variação geográfica. O objetivo deste trabalho foi testar se há relação entre morfologia dental, sexo, comprimento do corpo e idade. Foram analisados 91 espécimens de $P$. blainvillei e 80 espécimens de $S$. fluviatilis capturados acidentalmente em pescarias ou encalhados no Norte do Rio de Janeiro ( $\left.21^{\circ} 37^{\prime}-22^{\circ} 25^{\prime} \mathrm{S}\right)$, no período entre setembro de 1988 e novembro de 1996. O diâmetro da raiz do dente em exemplares de P. blainvillei diferiu significativamente entre os sexos; os valores nas fêmeas foram maiores do que os valores nos machos. Em nenhuma espécie foi observada significância nas variações na dimensão e no número de dentes, na espessura das camadas de crescimento na dentina e no cimento e na largura máxima do cimento como função do comprimento corpóreo. A idade foi relacionada ao incremento do comprimento do dente, dos diâmetros da raiz e do cíngulo e da largura máxima do cimento nos indivíduos de P. blainvillei, e no incremento dos comprimentos do dente e da coroa e da largura máxima do cimento nos indivíduos de $S$. fluviatilis. A relação linear entre os valores de largura máxima do cimento e a idade em ambas 
as espécies indica que as equações obtidas podem ser utilizadas para estimar a idade relativa em $P$. blainvillei e S. fluviatilis no norte do Rio de Janeiro.

Palavras-chave: Pontoporia blainvillei, Sotalia fluviatilis, morfologia dental, idade, pequenos cetáceos.

\section{INTRODUCTION}

From the seven species of small cetaceans accidentally captured in fisheries or stranded in northern Rio de Janeiro (1988-1996), Pontoporia blainvillei and Sotalia fluviatilis were the most frequent. The incidental captures occurred in gillnets, involving mainly $P$. blainvillei between zero and two years old, and $S$. fluviatilis between four and six years old (Di Beneditto, 1997; Ramos, 1997).

The relationship among dental morphology, sex, body length and age of small cetaceans can be used to estimate dimorphism, ontogeny or geography of carcasses in advanced decomposition or when it is impossible to identify sex or body length (Akin, 1988; Lowry \& Folk, 1990). Dental morphology has been applied as a determinant of populations stocks, e.g. using morphological variation in teeth from different populations of Stenella longirostris and its relationship to latitude increase (Akin, 1988). Canine teeth size has also been used to sex California Sea Lions (Zalophus californianus californianus) whose sex could not be determined by tradicional methods (Lowry \& Folk, 1990).

Heras et al. (1994) analysed the morphology of tooth of P. blainvillei to establish a functional dental organization. They ascertained that although the species is considered homodonte, there is morphological variation linked to different functions of its dental pieces in each implanted area. Schmiegelow (1990) analysed the correlation between the diameter of the pulp cavity and the number of growth layers in teeth of $S$. fluviatilis. He verified that the relationship between diameter of pulp cavity and number of growth layers can be considered in the estimate of age in this species.

The objective of this study was to determine the relationship between dental morphology, sex, body size and age in P. blainvillei and S. fluviatilis accidentally captured in fisheries or stranded in northern Rio de Janeiro (1988-1996).

\section{MATERIAL AND METHODS}

We analysed 91 individuals of $P$. blainvillei and 80 individuals of $S$. fluviatilis accidentally captured in gillnet fisheries or stranded from September 1988 to November 1996. Details of fishing operations and individuals collected can be seen in Di Beneditto (1997) and Ramos (1997).

Body length (BL-cm) was measured in a straight line from the tip of the upper jaw to the notch of the fluke. The number of teeth of each individual was registered by hemi-arch. The results were grouped in: 1. total number of teeth (TNT); 2. total number of teeth of right and left upper hemiarch (NTU); 3. total number of teeth of right and left lower hemi-arch (NTLo); 4. total number of teeth of upper and lower right hemi-arch (NTR); 5. total number of teeth of upper and lower left hemi-arch (NTLe).

A total of five measurements was taken at the external surface of each tooth: 1. tooth length, measured of the extremity apical of crown to the end of the root (TL-mm); 2. crown length, measured of the extremity apical of the crown to the cingulum of the root (CL-mm); 3. crown diameter, measured in the maximum width of crown (CD-mm); 4. root diameter, measured in the maximum width of root (RD-mm); 5. cingulum diameter, measured in the maximum width in the intersection of the crown with the root (CID-mm) (Fig. 1), following methodology described by Borobia (1984).

Age was estimated based on the growth layers groups (GLGs) (Perrin \& Myrick, 1980) present in the dentine and cementum of teeth. The growth layers of $P$. blainville $i$ were counted in the dentine and cementum. For individuals of $S$. fluviatilis, the counts were made in the dentine layers only. The last complete layer was considered for age determination in both species: we avoided fractions of layers. Teeth were fixed in $10 \%$ formalin, decalcified in RDO (a commercial decalcifying agent) and sectioned on a freezing microtome using sagittal and parasagittal cuts, following the 
methodology described by Hohn et al. (1989) and Perrin \& Myrick (1980). Sections were then stained with Mayer's haematoxylin for 30 minutes and mounted in glycerin.

Seven measurements was taken of the sections of teeth using an ocular micrometer, as follows: (i) first dentinal GLG, measured in the area between the base of neonatal line up to the second unstainable dentine layer (1D- $\mu \mathrm{m})$; (ii) second dentinal GLG, measured in the area between the second layer unstainable up to the third unstainable layer $(2 \mathrm{D}-\mu \mathrm{m})$; (iii) third dentinal GLG, measured in the area between the third layer
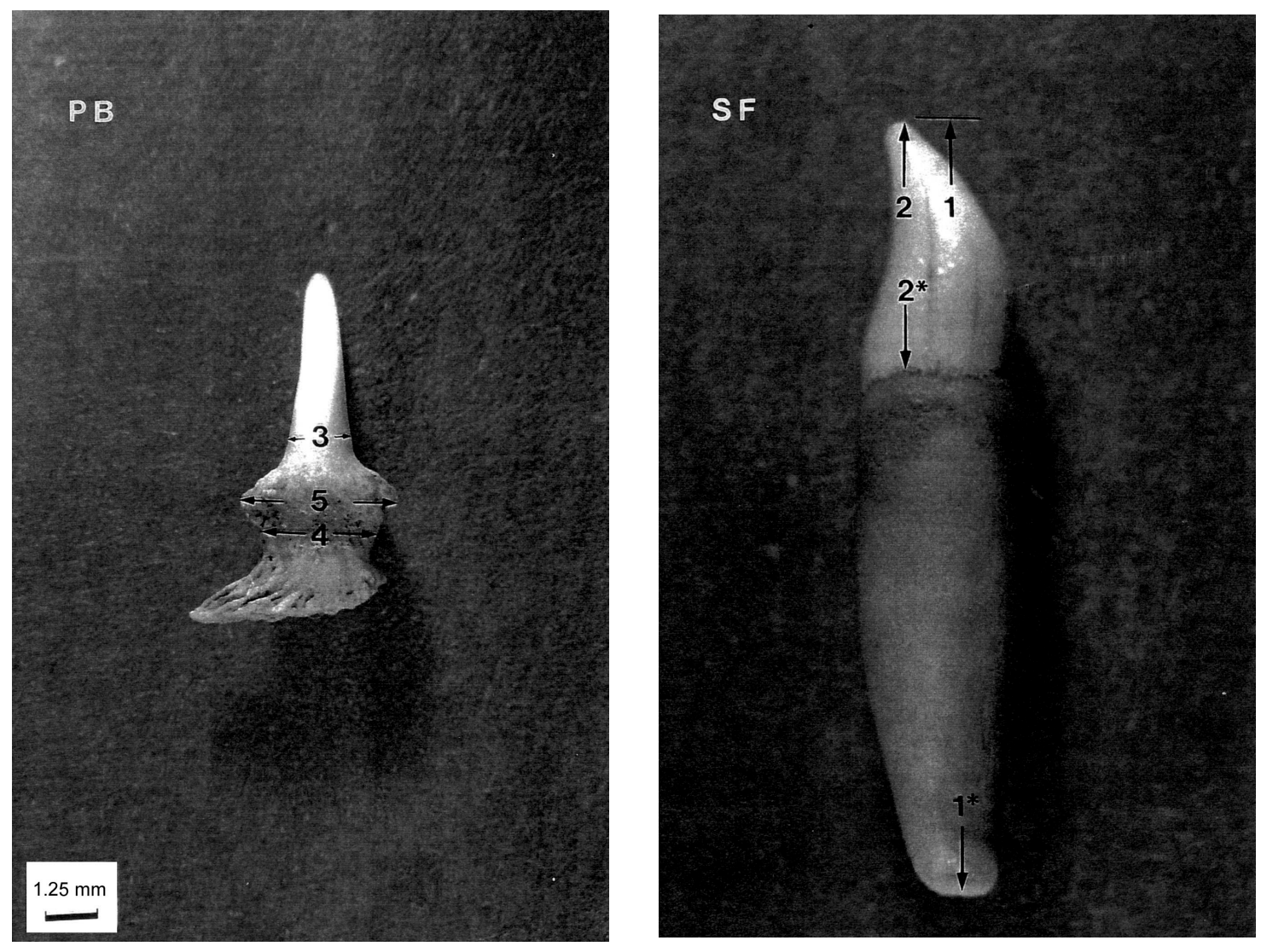

Fig. 1 - Photographs of the teeth of individuals adults of Pontoporia blainvillei (PB) and Sotalia fluviatilis (SF), indicating the five measurements taken at external surface of the tooth $\left(1-1^{*}=\right.$ tooth length; $2-2^{*}=$ crown length; $3=$ crown diameter; 4 = root diameter and $5=$ cingulum diameter) (Photographs: Márcia Adriana C. Dutra). 

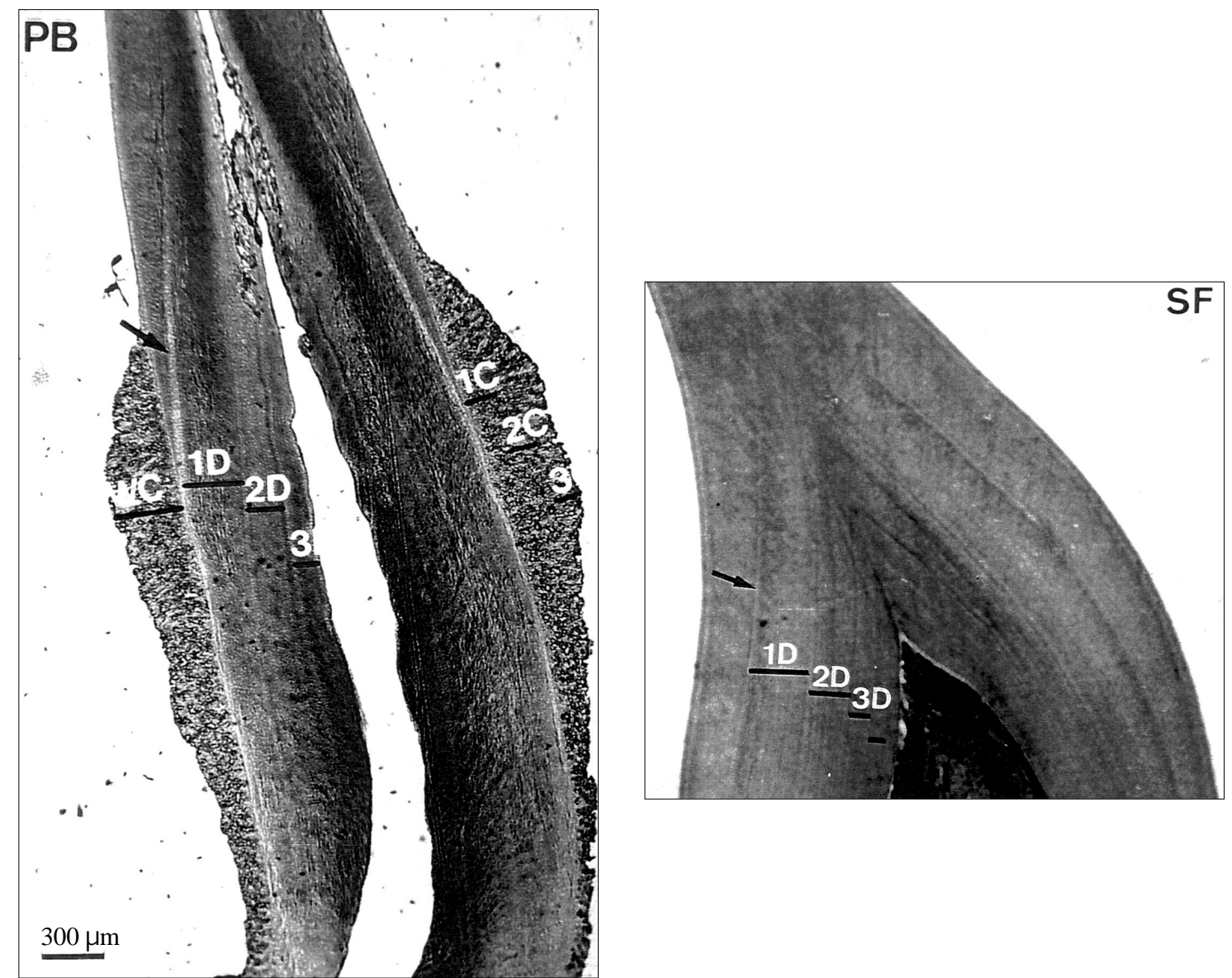

Fig. 2 - Photographs of longitudinal cuts of the teeth indicating the measurements taken in the surface of the sections: (PB) a individual male of Pontoporia blainvillei, with three dentinal layers and three cemental layers; (SF) a individual male of Sotalia fluviatilis, with four dentinal layers. The symbol arrow $(\rightarrow)$ indicates the neonatal line $(1 \mathrm{D}=1 \mathrm{st}$ dentinal GLG; $2 \mathrm{D}=$ 2nd dentinal GLG; 3D = 3rd dentinal GLG; $1 \mathrm{C}=1$ st cemental GLG; $2 \mathrm{C}=2$ nd cemental GLG; 3C $=3 \mathrm{rd}$ cemental GLG; WC = maximum width of the cement) (Photographs: Márcia Adriana C. Dutra).

All the seven measurements mentioned above were taken in the individuals of P. blainvillei. For S. fluviatilis, the measures of thickness of cemental layers (iv-vi) were not taken in the teeth because of the difficulty of distinguishing the limit among cemental layer in this species.

Sexual dimorphism in relation to body length was reported previously in this species (Kasuya \& Brownell, 1979; Pinedo, 1991; Ramos, 1997). Therefore, to verify if the teeth and thickness dimensions of the growth layers in the dentine and cement differed with body length, the individuals of $P$. blainville $i$ were separated by sex. In other hand, individuals of $S$. fluviatilis were analysed without sex distinction, because the sexual dimorphism in relation to body length was not verified in this species (Borobia, 1989; Ramos, 1997).

The effect of sex, body size and age in tooth growth were tested using Mann Whitney-U test and Kruskal-Wallis test and correlation among body length or age and teeth dimensions and thickness of the growth layers of dentine and cement were tested using the Spearman's Correlation through of the Statistic for Windows and SAS statistical programs (SAS, 1989; Sokal \& Rohlf, 1995). 


\section{RESULTS}

\section{Morphology and number of teeth}

The teeth of $P$. blainvillei are small and fine (Fig. 1). The crown is compressed antero-posteriorly and mesially curved for the lingual face, while the root is flattened in the lingual-buccal direction and its distal portion warped toward the posterior area of the jaw. The portion of the cervix of the tooth in the intersection between dentine and cement formed a thick cingulum. The teeth of $S$. fluviatilis are robust and conical (Fig. 1). The crown is flat and the point apical curved for the lingual direction. The cervix of the teeth forms a cingulum slightly more strait than the root.

Males and females of $P$. blainvillei presented tooth length (TL) ranged from 6.2 to $9.0 \mathrm{~mm}$ and 6.4 to $9.1 \mathrm{~mm}$; crown length (CL) from 3.4 to $5.5 \mathrm{~mm}$ and 3.1 to $5.5 \mathrm{~mm}$; crown diameter (CD) from 1.6 to 2.4 $\mathrm{mm}$ and 1.5 to $2.8 \mathrm{~mm}$; root diameter (RD) from 1.4 to $2.5 \mathrm{~mm}$ and 1.4 to $4.5 \mathrm{~mm}$; and cingulum diameter (CID) from 1.5 to $3.5 \mathrm{~mm}$ and 1.6 to $4.4 \mathrm{~mm}$, respectively. Males and females of $S$. fluviatilis presented TL ranged from 8.5 to $19.3 \mathrm{~mm}$ and 13.1 to $19.5 \mathrm{~mm}$; CL from 2.4 to $7.5 \mathrm{~mm}$ and 5.7 to $8.2 \mathrm{~mm}$; CD from 3.1 to $4.3 \mathrm{~mm}$ and 3.7 to $4.5 \mathrm{~mm}$; RD from 3.6 to $5.0 \mathrm{~mm}$ and 3.7 to $5.0 \mathrm{~mm}$; and CID from 3.2 to $4.6 \mathrm{~mm}$ and 3.5 to $4.7 \mathrm{~mm}$, respectively.

Sexual dimorphism was observed in the RD of $P$. blainvillei (U: $\mathrm{Z}_{\text {adjust }}=-2.837 ; n=89 ; P \leq$ $0.05)$. No sexual dimorphism was observed in relation to teeth size $(P>0.05)$ for $S$. fluviatilis. There was no significant difference $(P>0.05)$ for the dimensions of teeth in function of body length in both species.

For $P$. blainvillei, significant age differences were observed for tooth length (K.W.: TL: $\chi^{2}=$ 40.767; g.l. $=13 ; P \leq 0.05)$, root diameter (K.W.: RD: $\chi^{2}=49.073 ;$ g.l. $\left.=12 ; P \leq 0.05\right)$, and cingulum diameter (K.W.: CID: $\chi^{2}=52.054$; g.l. $=12 ; P \leq 0.05$ ). A significant positive correlation was observed between age and the variables tooth length, root diameter and cingulum diameter (TL: $r_{\mathrm{S}}=0.56$; g.l. $=$ $80 ; P \leq 0.05$ / RD: $r_{\mathrm{S}}=0.68 ;$ g.l. $=79 ; P \leq 0.05 /$ CID: $\left.r_{\mathrm{s}}=0.82 ; \mathrm{g} .1 .=79 ; P \leq 0.05\right)$.

Age significantly affected tooth length (K.W.: TL: $\chi^{2}=32.523 ;$ g.1. $\left.=14 ; P \leq 0.05\right)$ and crown length (K.W.: CL: $\chi^{2}=25.589$; g.1. $\left.=14 ; P \leq 0.05\right)$ in S. fluviatilis. A significant negative correlation between age and crown length $\left(\mathrm{CL}: r_{\mathrm{S}}=-0.32\right.$; g.l. $=$
$65 ; P \leq 0.05)$ was found for this species. However, there was no significant correlation between age and tooth length (TL: $r_{\mathrm{S}}=0.24$; g.1. $=$ $66 ; P>0.05)$.

The ranges of the number of teeth on each hemi-arch for males and females of $P$. blainvillei varied from 50 to 63 and 53 to 62 , respectively. The number of teeth on each hemi-arch in S. fluviatilis varied from 30 to 37 for both sexes. There was no significant differences $(P>0.05)$ among the total number (TNT), bilateral position (NTR or NTLe) and jaw localization (NTU or NTLo) of the teeth as a function of sex, size or age for both species.

\section{Thickness of the growth layers}

In average, males and females of P. blainville $i$ presented $367.8 \mu \mathrm{m}$ and $375.9 \mu \mathrm{m}$ for first dentinal layer (1D); $184.8 \mu \mathrm{m}$ and $186.5 \mu \mathrm{m}$ for second dentinal layer (2D); $117.0 \mu \mathrm{m}$ and $105.0 \mu \mathrm{m}$ for third dentinal layer (3D); $170.0 \mu \mathrm{m}$ and $172.0 \mu \mathrm{m}$ for first cemental layer (1C); $126.9 \mu \mathrm{m}$ and $135.8 \mu \mathrm{m}$ for second cemental layer (2C) and $128.0 \mu \mathrm{m}$ and $121.7 \mu \mathrm{m}$ for third cemental layer (3C), respectively. Males and females of $S$. fluviatilis presented in average $297.8 \mu \mathrm{m}$ and $296.5 \mu \mathrm{m}$ for $1 \mathrm{D} ; 242.1 \mu \mathrm{m}$ and $237.8 \mu \mathrm{m}$ for $2 \mathrm{D} ; 177.0 \mu \mathrm{m}$ and $165.0 \mu \mathrm{m}$ for $3 \mathrm{D}$, respectively.

The thickness of growth layer in the first and second dentinal and cemental layers of $P$. blainvillei were larger in females than males. An opposition pattern was observed for the growth layer thickness of the third dentinal and cemental, the values of males were in average larger than females. In the species $S$. fluviatilis the mean values of thickness in the first, second and third dentinal of males were always larger than the means of females.

There were no significant sex, body size or age difference $(P>0.05)$ in the variation of the thickness of the first three growth layers in the dentine (1D, 2D and 3D) in both species and in the first three growth layers in the cement (1C, 2C and 3C) in P. blainvillei.

The maximum width of the cement (WC) ranged from 10 to $1,540 \mu \mathrm{m}$ in teeth of P. blainvillei, whereas in of $S$. fluviatilis, the variation was between 20 and $540 \mu \mathrm{m}$. Those variations WC did not show significance $(P>0.05)$ as a function of the sex and body size of the individuals in both species. 
The maximum width of cement differed significantly in function of the age for the individuals of $P$. blainvillei (K.W.: $\chi^{2}=68.959$; g.l. $=12 ; P \leq 0.05$ ), and for $S$. fluviatilis (K.W.: $\chi^{2}=41.837$; g.1. $=13 ; P \leq 0.05$ ), showing positive and significant correlation in both species $(P$. blainvillei: $r_{\mathrm{S}}=0.92 ;$ g.l. $=79 ; P \leq 0.05$ e $S$. fluviatilis: $r_{\mathrm{s}}=0.87$; g.l. $\left.=63 ; P \leq 0.05\right)$.

The relationship verified between maximum width of the cement and age in individuals of $P$. blainvillei and S. fluviatilis is represented by the following equations (Fig. 3):

$$
\begin{aligned}
& \mathrm{y}=150.61 \mathrm{x}^{1,1615}(\mathrm{r} 2=0.87 ; \mathrm{n}=90)(P . \text { blainvillei }) \\
& \mathrm{y}=21.187 \mathrm{x}^{0,8257}(\mathrm{r} 2=0.64 ; \mathrm{n}=75)(\text { S. fluviatilis })
\end{aligned}
$$

Where, $x=$ the age in years and $y=$ the maximum width of the cement.

\section{DISCUSSION}

The dental form of P. blainvillei and $S$. fluviatilis were similar to the patterns described in the literature (Carvalho, 1963; Heras et al., 1994).

The teeth are an important part of feeding apparatus, and dental morphology has a strong influence on the type of food consumed (Perrin, 1975; Watson, 1981). The difference in the tooth root diameter seen in P. blainvillei, with females values larger than males, could be a traits dimorphic between the individuals and could bring feeding advantages to females over males. However, so that this character can be considered dimorphism and in this way used to determine the sex, discriminantes functions should be generated.

None of the teeth traits analysed in S. fluviatilis were significantly affect by sex, and should not be used to identify animals of unknown sex.

In neither species the dimensions of teeth differentiate in relation to body length, indicating that the ranges observed reflect natural variation between individuals.

The effect of age on the cingulum and root diameter of $P$. blainvillei should be caused by prominence in the cingulum region formed by the deposition of the cemental layers. The inverse relationship between age and crown length observed in the teeth of $S$. fluviatilis might be related to tooth wear and can this be verified in older individuals. The wear in the tooth tips has been related to the age and use (Watson, 1981).

In neither species, were the number of teeth affected by sex, body length or age, indicating that the ranges observed reflect natural variation among individuals.

In northern Rio de Janeiro, the average thickness of the growth layers obtained in males and females of P. blainvillei were similar to the results obtained for individuals from South of Brazil and Uruguay (Kasuya \& Brownell, 1979; Pinedo, 1991). The scarcity of data of thickness of GLGs in teeth of $S$. fluviatilis hinders comparisons among different populations.

Age determination has become standard procedure in the assessment and management of marine mammal stocks (Scheffer \& Myrick, 1980). The method of age estimates through growth layers groups (GLGs) (Perrin \& Myrick, 1980) has been successfully used to estimate age in several species of small cetaceans from tropical waters such as, Stenella attenuata, Tursiops truncatus, Phocoena sinus, P. blainvillei and S. fluviatilis (Sergeant et al., 1973; Kasuya, 1976; Perrin et al., 1976; Cockcroft \& Ross, 1989; Kasuya \& Brownell, 1979; Van Utrecht, 1981; Borobia, 1989; Hohn et al., 1989; Pinedo, 1991; Calzada et al., 1994; Hohn et al., 1996).

The growth layer patterns and relative size of the layers are very similar in many delphinids. The inter-specific variation occurs in the deposition ratio. Therefore, the medium thickness of dentinal and cemental layers has been considered useful in the identification of the growth layers groups. The relative growth layers thickness described can be used as a model and applied to other species for which the layers have not been calibrated (Hohn et al., 1989). The means values of the growth layers thickness in the dentine and cement obtained in this study can favour the identification of the growth layers in other specimens of $P$. blainvillei and $S$. fluviatilis.

The relationship among the maximum width of cement and age in both species, corroborates literature confirming that the cement registers the individual's complete ontogeny. Dentinal and cemental layering is probably influenced by the same physiological mechanism, however, the pulpcavity usually fills occlusion and can interrupt or decrease the deposition ratio of the dentinal layers (Myrick, 1980). 

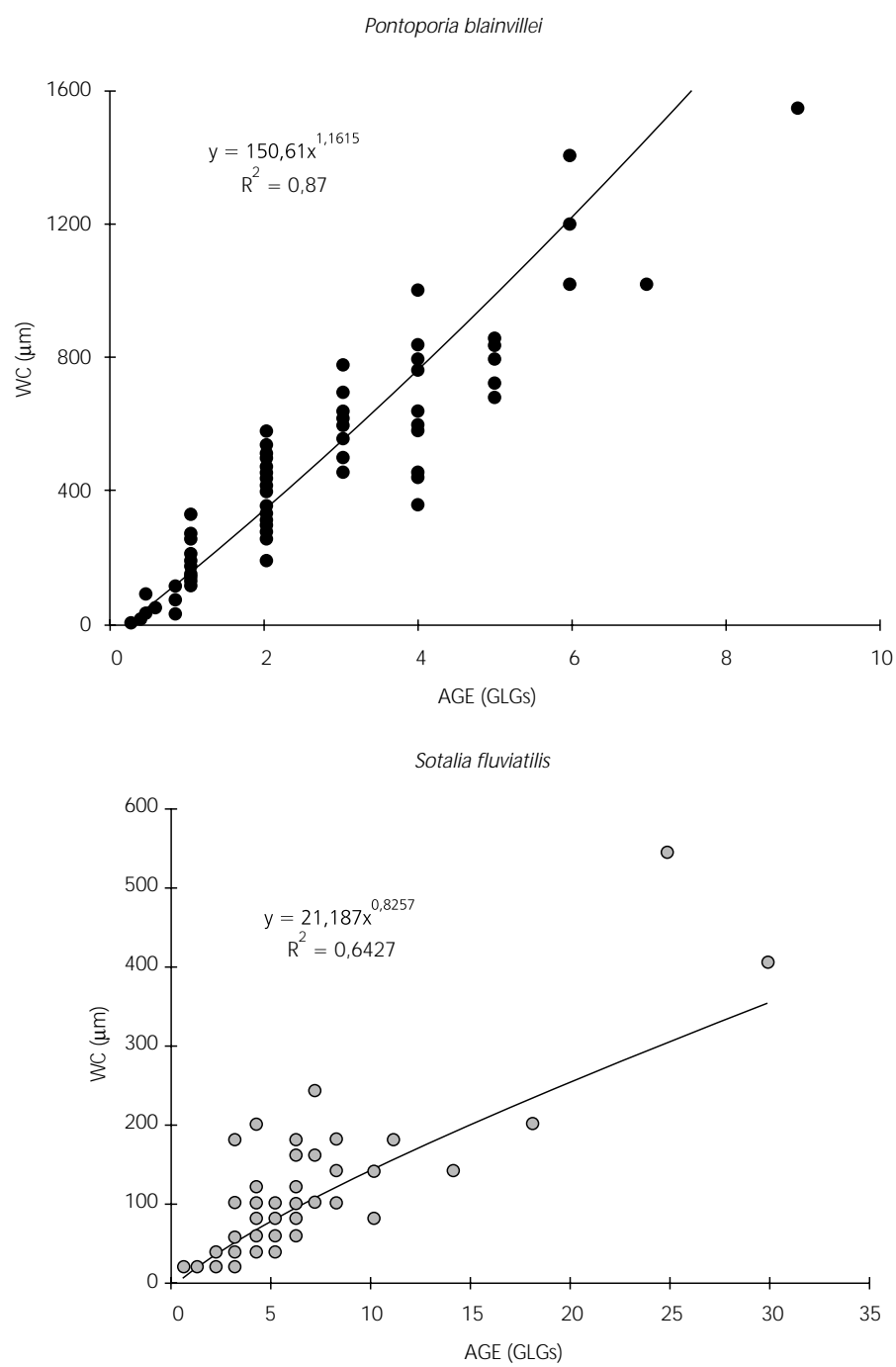

Fig. 3 - Relationship among age (Age-GLGs) and maximum width of the cement (WC- $\mu \mathrm{m})$ in specimens of Pontoporia blainvillei and Sotalia fluviatilis.

The formation of cemental layers occurs in the external surface of the tooth's basal half and its accumulation is verified until death. Therefore, this tissue should represent an uninterrupted layered recording of the entire postnatal life and this may be used to estimates ages of old animals (Myrick, 1991).

The equations obtained from the relationship between maximum width cement and age in both species, can be used as parameters to estimate the relative age in specimens of $P$. blainvillei and $S$. fluviatilis in northern Rio de Janeiro. This technique is useful when it is not possible to estimate age by growth layers group in the dentine and cement due to logistics problems such as equipment, histological procedures or technician accuracy in the interpretation of growth layers with necessary sharpness.

Acknowledgments - We thank our colleagues of Projeto Cetáceos/Fundação Brasileira para a Conservação da Natureza $(\mathrm{FBCN})$ and the fishermen of Atafona for the collaboration during the collection of data; to Salvatore Siciliano and Carlos Ruiz-Miranda for comments on the manuscript; to Petróleo Brasileiro S/A (Petrobras) for the financial support to this study; Universidade Estadual do Norte Fluminense (UENF) for the institutional support; Fundação Estadual do Norte Fluminense (Fenorte) for the fellowship to Renata M. A. Ramos and Ana Paula M. Di Beneditto and Conselho Nacional de Desenvolvimento 
Científico e Tecnológico (CNPq - Proc. 352085/96-7) for the fellowship to Neuza Rejane W. Lima.

\section{REFERENCES}

AKIN, P. A., 1988, Geographic Variation in tooth morphology and dentinal patterns in the spinner dolphin, Stenella longirostris. Mar. Mammal Sci., 4(2): 132140 .

BOROBIA, M., 1984, Comportamento e aspectos biológicos dos botos da Baía de Guanabara, Sotalia sp. Monografia de Bacharelado, Universidade do Estado do Rio de Janeiro, Rio de Janeiro, 81p.

BOROBIA, M., 1989, Distribution and morphometrics of South American dolphins of the genus Sotalia. Master Thesis, Macdonald College of McGill University, Montreal, Quebec, 80p.

CALZADA, N., LOCKYER, C. H. \& AGUILAR, A., 1994, Age and sex composition of the striped dolphin die-off in the Western Mediterranean. Mar. Mammal Sci., 10(3): 299-310.

CARVALHO, C. T., 1963, Sobre um boto comum no litoral do Brasil. Rev. Brasil. Biol., Rio de Janeiro, 23 (3): 263-276.

COCKCROFT, V. G. \& ROSS, G. J. B., 1989, Age, growth and reproduction of bottlenose dolphins Tursiops truncatus from the East Coast of Southern Africa. Fish. Bull., 88: 289-302.

DI BENEDITTO, A. P., 1997, Captura acidental de pequenos cetáceos em rede de espera: uma ameaça às populações do Norte do Rio de Janeiro? Tese de Mestrado, Universidade Estadual do Norte Fluminense, Campos, Rio de Janeiro, 91p.

HERAS, M. P., JUNIN, M. \& CASTELLO, H. P., 1994, Morfologia dental en Pontoporia blainvillei (Gervais \& D’Orbigny, 1844). Anais da IV Reunión de Trabajos de Especialistas en Mamíferos Acuáticos de America del Sur, 1990, Valdivia, pp. 171-176.

HOHN, A. A., SCOTH, M. D., WELLS, R. S., SWEENEY, J. C. \& IRVINE, A. B., 1989, Growth layers in teeth from known age, free-ranging bottlenose dolphins. Mar. Mammal Sci., 5(4): 315-342.

HOHN, A. A., READ, R. J., FERNANDEZ, S., VIDAL, O. \& FINDLEY, L. T., 1996, Life history of the vaquita, Phocoena sinus (Phocoenidae, Cetacea). J. Zool., Lond, 239: 235-251.

KASUYA, T., 1976, Reconsideration of life history parameters of the spotted and striped dolphins based on cemental layers. Sci. Rep. Whales Res. Inst., Tokyo, 28: 73-106.

KASUYA, T. \& BROWNELL JR., R. L., 1979, Age determination, reproduction and growth of the franciscana dolphin, Pontoporia blainvillei. Sci. Rep. Whales Res. Inst., Tokyo, 31: 43-67.

LOWRY, M. S. \& FOLK, R. L., 1990, Sex determination of the California sea lion (Zalophus californianus californianus) from canine teeth. Mar. Mammal Sci., 6(1): 25-31.
MYRICK JR., A. C., 1980, Examination of Layered Tissues of Odontocetes for Age Determination using Polarizad Light Microscopy. Rep. Int. Whal. Commn (special issue, 3): 105-112.

MYRICK JR., A. C., 1991, Some New and Potential Uses of Dental Layers in Studying Delphinid Populations. In: K. Pryor \& K. S. Norris (eds.), Dolphin Societies, Discoveries and Puzzles. University of California Press, pp. 251-279

PERRIN, W. F., 1975, Variation in spotted and spinner porpoise (genus Stenella) in the eastern Tropical Pacific and Hawaii. Bull. Scripps Inst. Oceanogr. Tech Ser., 21: 206p.

PERRIN, W. F., COL, J. M. \& ZWEIFEL, J. R., 1976, Growth and reproduction of the spotted porpoise, Stenella attenuata, in the offshore Eastern Tropical Pacific. Fish. Bull., 74(2): 229-270.

PERRIN, W. F. \& MYRICK JR., A. C. (eds.), 1980, Age determination of toothed whales and sirenians. Rep. Int. Whal. Commn, Cambridge, 3: 229p.

PINEDO, M. C., 1991, Development and variation of the franciscana, Pontoporia blainvillei. PhD Thesis, University of California, 406p.

RAMOS, R., 1997, Determinação de idade e biologia reprodutiva de Pontoporia blainvillei e de Sotalia fluviatilis (Cetacea: Pontoporiidae e Delphinidae) no Norte do Rio de Janeiro. Tese de Mestrado, Universidade Estadual do Norte Fluminense, Campos, Rio de Janeiro, 95p.

SAS INSTITUTE INC., 1989, SAS user's guide. Version 6, fourth edition, Cary, NC: SAS Institute Inc., vol. 1, 943p., vol. 2, 846p.

SCHEFFER, V. B. \& MYRICK JR., A. C., 1980, A Review of studies to 1970 of growth layers in teeth of marine mammals. Rep. Int. Whal. Commn, Cambridge, 3: 5163.

SCHMIEGELOW, J. M. M., 1990, Estudo sobre cetáceos odontocetos encontrados em praias da região entre Iguape (SP) e Baía de Paranaguá (PR) (24² $42^{\prime} S$ $\left.25^{\circ} 28^{\prime} S\right)$ com especial referência a Sotalia fluviatilis (Gervais, 1853) (Delphinidae). Tese de Mestrado, Universidade de São Paulo, 149p.

SERGEANT, D. E., CALDWEEL, D. K. \& CALDWEEL, M. C., 1973, Age, growth and maturity of botlenosed dolphin (Tursiops truncatus) from Northeast Florida. J. Fish Res. Board Can, 30: 1009-1011.

SOKAL, R. R. \& ROHLF, F. J., 1995, Biometry: the principles and pratictice of statistics in biological research. W. H. Freeman and Company, New York, 3d ed., $850 \mathrm{p}$.

VAN UTRECHT, W. L., 1981, Comparison of accumulation patterns in layered dentinel tissue of some Odontoceti and corresponding patterns in baleen plates and ear plugs, of Balaenopteridae. Institute of Taxonomic Zoology (Zoological Museum), University of Amsterdam, 31(6): II1-II9/I20-I22.

WATSON, L., 1981, Sea guide to whales of the world. E. P. Dutton, New York, 302p. 